\title{
MEDIASI SEBAGAI UPAYA HAKIM MENEKAN PERCERAIAN DI PENGADILAN AGAMA
}

\author{
Adiyono \\ (Program Pascasarjana UIN Sunan Ampel Surabaya, jln. A. Yani 117 \\ Surabaya, email: adiy@gmail.com)
}

\begin{abstract}
Abstrak
Mediasi mendapat kedudukan penting dalam PERMA nomor 1 tahun 2008, karena proses mediasi merupakan bagian yang tidak terpisahkan dari proses beperkara di pengadilan. Berkenaan dengan pelaksanaan PERMA nomor 1 tahun 2008 di Pengadilan Agama Bangkalan, jika ada para pihak yang berperkara, hakim berupaya melakukan upaya damai dan mewajibkan pada para pihak untuk melakukan proses mediasi. Pengadilan agama juga memberikan keleluasaan kepada kedua belah pihak untuk menentukan mediator. Mediator yang berasal dari lembaga mediasi, advokat, atau individu harus mempunyai sertifikat mediasi dari Pengadilan Agama Bangkalan. Secara formal hakim mediator Pengadilan Agama Bangkalan memfasilitasi para mediator selama dua pekan (15 hari) atau lebih, jika para pihak menghendaki perpanjangan mediasi sampai 40 hari. Namun demikian, model kerja mediasi hampir mirip dengan bentuk nasihat dan penggalian data masalah, tanpa melaui konsep yang matang, sebagaimana tahapan teori mediasi.
\end{abstract}

\begin{abstract}
Mediation gets important position in PERMA number 1 in 2008, because mediation process is a part that cannot be separated from the process of litigant in the court. Related to the establishment of PERMA number 1 in 2008 in religious court of Bangkalan, if there is a litigant, the judge tries to do the peaceful effort and requires to both litigant to do mediation process. It also gives discretion to them in deciding a mediator. The mediator is from mediation institution, lawyers or individual that must have mediation sertificate from religious court of Bangkalan. Formally, mediator judge facilitates all mediators for two weeks (15 days) or more, but if they want to have prolongation of mediation, it can be for 40 days. However, the work model of mediation is rather similar with suggestion
\end{abstract}


form and studies of problem data, without having the good concept, as the steps of mediation theory.

Kata-kata Kunci

Mediasi, mediator, hakim, perceraian, pengadilan agama

\section{Pendahuluan}

Peraturan Mahkamah Agung RI No. 1 tahun 2008 tentang Prosedur Mediasi di Pengadilan adalah penyempurnaan atas Peraturan Mahkamah Agung RI no. 2 tahun 2003 tentang Prosedur Mediasi di Pengadilan. Penyempurnaan tersebut dilakukan Mahkamah Agung karena dalam PERMA no. 2 tahun 2003 ditemukan beberapa masalah, sehingga tidak efektif penerapannya di pengadilan. Mahkamah Agung mengeluarkan PERMA no. 1 tahun 2008 sebagai upaya mempercepat, mempermurah, dan mempermudah penyelesaian sengketa serta memberikan akses yang lebih besar kepada pencari keadilan. Mediasi merupakan instrumen efektif untuk mengatasi penumpukan perkara di pengadilan sekaligus memaksimalkan fungsi lembaga pengadilan dalam menyelesaikan sengketa, di samping proses pengadilan yang bersifat memutus (adjudikatif). ${ }^{1}$

Begitu juga dengan yang disampaikan oleh Sugiri Permana, bahwa lahirnya acara mediasi melalui PERMA nomor 1 tahun 2008 (kemudian akan disebut PERMA), merupakan penegasan ulang atas PERMA sebelumnya, yaitu PERMA nomor 2 tahun 2003. Dilatarbelakangi oleh menumpuknya perkara di lingkungan peradilan, terutama dalam perkara kasasi, mediasi dianggap sebagai instrumen efektif dalam proses penyelesaian sengketa yang lebih cepat dan murah, serta dapat memberikan akses yang lebih besar kepada para pihak untuk menemukan penyelesaian yang memuaskan dan memenuhi rasa keadilan. ${ }^{2}$

Selanjutnya, keberadaan mediasi sebagai bagian dalam hukum acara perdata dapat dianggap sebagai salah satu sumbangan berharga dari Bagir Manan pada masa jabatannya. Pasal 130 HIR/154 RBG

\footnotetext{
1 Syahrizal Abbas, Mediasi dalam Perspektif Hukum Syari'ah, Hukum Adat dan Hukum Nasional (Jakarta: Fajar Interpratama offset, 2009), hlm. 310.

2 Sugiri Permana, "Mediasi dan Hakam dalam Tinjauan Hukum Acara Peradilan Agama", Mari (2009).
} 
yang memerintahkan usaha perdamaian oleh hakim dijadikan sebagai modal utama dalam membangun perangkat hukum ini, yang sudah dirintis sejak tahun 2002 melalui SEMA nomor 1 tahun 2002 tentang Pemberdayaan Pengadilan Tingkat Pertama Menerapkan Lembaga Damai pasal $130 \mathrm{HIR} / 154$ RBg yang kemudian pada tahun 2003 disempurnakan melalui PERMA nomor 2 tahun 2003 tentang Prosedur Mediasi di Pengadilan.

Kehadiran PERMA nomor 1 tahun 2008 dimaksudkan untuk memberikan kepastian, ketertiban, dan kelancaran dalam proses mendamaikan para pihak untuk menyelesaikan suatu sengketa perdata. Hal ini dapat dilakukan dengan mengintensifkan dan mengintegrasikan proses mediasi ke dalam prosedur berperkara di pengadilan. Mediasi mendapat kedudukan penting dalam PERMA nomor 1 tahun 2008, karena proses mediasi merupakan bagian yang tidak terpisahkan dari proses beperkara di pengadilan. Hakim wajib mengikuti prosedur penyelesaian sengketa melalui mediasi, bila hakim melanggar atau enggan menerapkan prosedur mediasi, maka putusan hakim tersebut batal demi hukum (Pasal 2 ayat (3) PERMA). ${ }^{3}$

\section{Definisi Mediasi}

Secara etimologi, mediasi berasal dari bahasa latin mediare yang berarti berada di tengah. Makna ini menunjuk pada peran yang ditampilkan pihak ketiga sebagai mediator dalam menjalankan tugasnya menengahi dan menyelesaikan sengketa di antara pihakpihak yang bersengketa. Berada di tengah juga bermakna sebagai mediator, karena ia harus berada pada posisi netral dan tidak memihak dalam menyelesaikan sengketa. Ia harus mampu menjaga kepentingan para pihak yang bersengketa secara adil dan sama, sehingga menumbuhkan kepercayaan pihak yang bersengketa. ${ }^{4}$

Mediasi juga diartikan sebagai proses pengikutsertaan pihak ketiga dalam penyelesaian suatu perselisihan sebagai penasihat. ${ }^{5}$ Menurut Syahrizal Abbas, definisi mediasi tersesut mengandung tiga

\footnotetext{
3 Abbas, Mediasi, hlm. 311.

4 Ibid., hlm. 2.

5 Tim Penyusun Pusat Pembinaan dan Pengembangan Bahasa, Kamus Besar Bahasa Indonesia (Jakarta: Departemen Pendidikan dan Keudayaan, 2007), hlm. 726.
} 
unsur penting, yakni: Pertama, mediasi merupakan proses penyelesaian perselisihan atau sengketa yang terjadi antara dua pihak atau lebih. Kedua, pihak yang terlibat dalam penyelesaian sengketa adalah pihak-pihak yang berasal dari luar pihak yang bersengketa. Ketiga, pihak yang terlibat dalam penyelesaian sengketa tersebut bertindak sebagai penasihat dan tidak memiliki kewenangan apa pun dalam pengambilan keputusan. ${ }^{6}$

Secara terminologi, mediasi adalah salah satu bentuk negosiasi antara dua individu atau kelompok dengan melibatkan pihak ketiga dengan tujuan membantu tercapainya penyelesaian yang bersifat kompromistik atau salah satu cara menyelesaikan masalah diluar pengadilan. Menurut Priatna Abdurrasyid, mediasi adalah suatu proses damai di mana para pihak yang bersengketa menyerahkan penyelesaiannya kepada seorang mediator (seorang yang mengatur pertemuan antara dua pihak atau lebih yang bersengketa) untuk mencapai hasil akhir yang adil, tanpa biaya besar, tetapi tetap efektif dan diterima sepenuhnya oleh kedua belah pihak yang bersengketa. ${ }^{7}$ Sedangkan menurut PERMA nomor 01 tahun 2008, mediasi adalah cara penyelesaian sengketa melalui proses perundingan untuk memperoleh kesepakatan para pihak dengan dibantu oleh mediator.8

Masih banyak pendapat lainnya yang memberikan penekanan yang berbeda tentang mediasi. Meski banyak yang memperdebatkan mengenai apa sebenarnya yang dimaksud dengan mediasi, namun setidaknya ada beberapa batasan atau definisi yang bisa dijadikan acuan. Salah satu di antaranya adalah definisi yang diberikan oleh The National Alternative Dispute Resolution Advisory Council yang mendefinisikan mediasi sebagai sebuah proses di mana pihak-pihak yang bertikai, dengan bantuan dari seorang praktisi resolusi pertikaian (mediator) mengidentifikasi isu-isu yang dipersengketakan, mengembangkan opsi-opsi, mempertimbangkan alternatif-alternatif, dan upaya untuk mencapai sebuah kesepakatan. Dalam hal ini, sang mediator tidak memiliki peran menentukan dalam kaitannya dengan isi/materi persengketaan atau hasil dari

${ }_{6}$ Abbas, Mediasi, hlm. 3

7 Zainuddin Fajari, "Mediasi", Makalah disampaikan pada acara Orientasi Peningkatan Kemampuan Kepemimpinan Hakim Pengadilan Agama di Surabaya 15 April 2009.

8 PERMA No. 01 Tahun 2008. 
resolusi persengketaan tersebut, tetapi ia (mediator) dapat memberi saran atau menentukan sebuah proses mediasi untuk mengupayakan sebuah resolusi/penyelesaian). ${ }^{9}$

Garry Goopaster memberikan definisi mediasi sebagai proses negosiasi pemecahan masalah dimana pihak luar yang tidak memihak (imparsial) bekerja sama dengan pihak-pihak yang bersengketa untuk membantu mereka memperoleh kesepakatan perjanjian yang memuaskan. Goopaster mencoba mengeksplorasi lebih jauh makna mediasi tidak hanya dalam pengertian bahasa, tetapi ia juga menggambarkan proses kegiatan mediasi, kedudukan, dan peran pihak ketiga, serta tujuan dilakukannya suatu mediasi. Goopaster jelas menekankan bahwa mediasi adalah proses negosiasi, di mana pihak ketiga melakukan dialog dengan pihak bersengketa dan mencoba mencari kemungkinan penyelesaian sengketa tersebut. Keberadaan pihak ketiga ditujukan untuk membantu pihak bersengketa mencari jalan pemecahannya, sehingga menuju perjanjian atau kesepakatan yang memuaskan kedua belah pihak.10

Jadi, secara singkat bisa digambarkan bahwa mediasi merupakan suatu proses penyelesaian pihak-pihak yang bertikai untuk mencapai penyelesaian yang memuaskan melalui pihak ketiga yang netral (mediator).

\section{Tujuan dan Manfaat Mediasi}

Penyelesaian sengketa memang sulit dilakukan, namun bukan berarti tidak mungkin diwujudkan dalam kenyataan. Modal utama penyelesaian sengketa adalah keinginan dan i'tikad baik para pihak dalam mengakhiri persengketaan mereka. Keinginan dan i'tikad baik ini, kadang-kadang memerlukan bantuan pihak ketiga dalam perwujudannya. Mediasi merupakan salah satu bentuk penyelesaian sengketa yang melibatkan pihak ketiga. Mediasi dapat memberikan sejumlah keuntungan antara lain: (1) mediasi diharapkan dapat menyelesaikan sengketa secara cepat dan relatif

\footnotetext{
9 David Spencer dan Michael Brogan, Mediation Law and Practice (Cambridge: Cambridge Univercuty Press, 2006), hlm. 9.

10 Gary Goopaster, Negosiasi dan Mediasi: Sebuah Pedoman Negosiasi dan Penyelesaian Sengketa melalui Negosiasi (Jakarta: Elips Project, 1993), hlm. 201.
} 
murah dibandingkan dengan membawa perselisihan tersebut ke pengadilan atau ke lembaga arbitrase; (2) mediasi akan memfokuskan perhatian para pihak pada kepentingan mereka secara nyata dan pada kebutuhan emosi atau psikologis mereka, sehingga mediasi bukan hanya tertuju pada hak-hak hukumnya; (3) mediasi memberikan kesempatan para pihak untuk berpartisipasi secara langsung dan secara informal dalam menyelesaikan perselisihan mereka; (4) mediasi memberikan para pihak kemampuan untuk melakukan kontrol terhadap proses dan hasilnya; (5) mediasi dapat mengubah hasil, yang dalam litigasi dan arbitrase sulit diprediksi, dengan suatu kepastian melalui suatu konsensus; (6) mediasi memberikan hasil yang tahan uji dan akan mampu menciptakan saling pengertian yang lebih baik di antara para pihak yang bersengketa karena mereka sendiri yang memutuskannya; (7) mediasi mampu menghilangkan konflik atau permusuhan yang hampir selalu mengiringi setiap putusan yang bersifat memaksa yang dijatuhkan oleh hakim di pengadilan atau arbiter pada lembaga arbitrase. ${ }^{11}$

\section{Resume Perma Nomor 1 Tahun 2008}

Peraturan Mahkamah Agung (PERMA) nomor 01 tahun 2008 tentang Prosedur Mediasi di Pengadilan ini ditetapkan pada tanggal 31 Juli 2008 dan berlaku sejak tanggal ditetapkannya. PERMA ini merupakan revisi sekaligus pengganti dari PERMA nomor 2 tahun 2003 tentang Prosedur Mediasi di Pengadilan. Beberapa catatan dari ketentuan yang terdapat pada PERMA No 01/2008, dapat penulis kemukakan sebagai berikut: Pertama, bagi lingkungan peradilan agama, PERMA ini lebih tegas dan lebih jelas mengenai pelaksanaan dan prosedur mediasi di lingkungan peradilan agama, dibanding PERMA nomor 2 tahun 2003. Dalam PERMA nomor 2 tahun 2003 pasal 16 disebutkan: "Apabila dipandang perlu ketentuan-ketentuan dalam Peraturan Mahkamah Agung ini, selain dipergunakan dalam lingkungan peradilan umum, dapat juga diterapkan untuk lingkungan badan peradilan lainnya". Sedangkan dalam PERMA nomor 01 tahun 2008 Bab I Ketentuan Umum, Pasal 1, angka 13 dan 14 disebutkan bahwa: "Pengadilan adalah Pengadilan Tingkat

11 Abbas, Mediasi, hlm. 24 - 26 
Pertama dalam lingkungan peradilan umum dan peradilan agama", dan "Pengadilan Tinggi adalah pengadilan tinggi dalam lingkungan peradilan umum dan peradilan agama".

Kedua, mengenai perkara yang dimediasi disebutkan sebagai berikut: Kecuali perkara yang diselesaikan melalui prosedur pengadilan niaga, pengadilan hubungan industrial, keberatan atas putusan Badan Penyelesaian Sengketa Konsumen, dan keberatan atas putusan Komisi Pengawas Persaingan Usaha, semua sengketa perdata yang diajukan ke Pengadilan Tingkat Pertama wajib lebih dahulu diupayakan penyelesaian melalui perdamaian dengan bantuan mediator (pasal 4).

Ketiga, mengenai kekuatan berlakunya PERMA, disebutkan antara lain bahwa tidak menempuh prosedur mediasi berdasarkan PERMA ini mengakibatkan putusan batal demi hukum (pasal 2). Keempat, mediator dapat dipilih seorang atau lebih dari hakim, advokat atau akademisi hukum, profesi bukan hukum yang dianggap menguasai atau berpengalaman dalam pokok perkara (pasal 8).

Kelima, mediator pada asasnya wajib memiliki sertifikat mediator yang diperoleh setelah mengikuti diklat yang diselenggarakan oleh lembaga yang terakreditasi oleh Mahkamah Agung. Jika di suatu wilayah pengadilan, tidak ada yang memiliki sertifikat, maka hakim di lingkungan pengadilan yang bersangkutan berwenang menjalankan fungsi mediator (pasal 5).

Keenam, untuk memperoleh akreditasi, sebuah lembaga harus memenuhi syarat-syarat: (1) mengajukan permohonan kepada Ketua MA-RI; (2) memiliki instruktur yang memiliki sertifikat telah mengikuti diklat mediasi dan diklat sebagai instruktur untuk diklat mediasi; (3) sekurang-kurangnya telah dua kali melaksanakan pelatihan mediasi bukan untuk mediator bersertifikat di pengadilan (pasal 5); (4) mengenai biaya pemanggilan para pihak, lebih dahulu dibebankan kepada penggugat, melalui uang panjar biaya perkara, kecuali ada kesepakatan lain. Jika tidak ada kesepakatan, hakim menentukan (pasal 3); (5) biaya jasa/honor mediator ditanggung bersama oleh para pihak atau berdasar kesepakatan. Hakim yang jadi mediator tidak mendapat bayaran jasa (pasal 10); (6) mediator wajib mempersiapkan jadwal pertemuan, mendorong para pihak untuk secara langsung berperan dalam mediasi dan mencari pilihan penyelesaian yang terbaik bagi para pihak. Jika diperlukan, mediator 
dapat melakukan pertemuan dengan salah satu pihak (pasal 15); (7) atas persetujuan para pihak, mediator dapat mengundang seorang atau lebih tenaga ahli yang terkait dengan persoalan (pasal 16); (8) tempat mediasi ditentukan atas kesepakatan para pihak. Khusus mediator hakim tidak boleh menyelenggarakan mediasi di luar pengadilan (pasal 20); (9) atas dasar kesepakatan, para pihak dapat menempuh upaya perdamaian, baik di tingkat pertama, banding, kasasi dan PK sepanjang perkara itu belum diputus (pasal 21); (10) sifat proses mediasi adalah tertutup, kecuali para pihak menentukan lain (pasal 6); dan (11) materi kesepakatan perdamaian tidak boleh bertentangan dengan hukum, harus dapat dilaksanakan dan tidak boleh memuat i'tikad yang tidak baik (pasal 17).

\section{Prosedur Mediasi menurut PERMA Nomor 1 Tahun 2008}

Secara garis besar prosedur mediasi menurut ketentuan PERMA nomor 1 tahun 2008 adalah sebagai berikut:

1) Pada sidang pertama, hakim mewajibkan para pihak pada hari itu juga atau paling lama 2 (dua) hari kerja berikutnya untuk berunding memilih mediator (pasal 11). Daftar mediator disediakan di pengadilan (pasal 9).

2) Para pihak segera menyampaikan mediator terpilih kepada ketua majelis hakim. Ketua majelis segera memberitau mediator untuk melaksanakan tugas (pasal 11).

3) Para pihak, jika gagal menyepakati mediator terpilih, wajib segera menyampaikannya kepada ketua majelis. Ketua majelis segera menunjuk hakim bukan pemeriksa perkara yang bersertifikat. Kalau tidak ada, maka hakim pemeriksa perkara, dengan atau tanpa sertifikat yang ditunjuk oleh ketua majelis wajib menjalankan fungsi mediator (pasal 11).

4) Paling lama 5 (lima) hari kerja setelah mediator disepakati, para pihak dapat menyerahkan resume perkara ${ }^{12}$ kepada satu sama lain dan kepada mediator. Jika para pihak gagal menyepakati mediator, maka resume perkara diberikan kepada hakim mediator yang ditunjuk (pasal 13).

\footnotetext{
12 Resume perkara adalah dokumen yang dibuat oleh tiap pihak yang memuat duduk perkara dan atau usulan penyelesaian perkara (pasal 1).
} 
5) Proses mediasi paling lama 40 hari kerja, dan dapat diperpanjang paling lama 14 hari kerja, atas dasar kesepakatan para pihak (pasal 13).

6) Mediator wajib menyatakan mediasi gagal, jika salah satu atau para pihak atau kuasa hukumnya telah dua kali berturut-turut tidak menghadiri pertemuan yang telah disepakati, atau tidak menghadiri pertemuan mediasi tanpa alasan setelah dipanggil secara patut (pasal 14).

7) Jika dicapai kesepakatan dalam mediasi, para pihak dan mediator menandatangani rumusan kesepakatan. Para pihak wajib menyampaikannya dalam sidang yang ditentukan dan dapat minta kesepakatan tersebut dikuatkan dalam bentuk akte perdamaian. Jika ada salah satu pihak tidak menghendaki kesepakatan itu dikuatkan dalam bentuk akte perdamaian, kesepakatan harus memuat klausul pencabutan gugatan atau klausula yang menyatakan perkara telah selesai (pasal 17).

8) Jika dalam waktu yang ditentukan, para pihak tidak mampu menghasilkan kesepakatan, mediator wajib menyatakannya secara tertulis dan memberitahukannya kepada hakim. Segera setelah itu, hakim melanjutkan pemeriksaan perkara sesuai hukum acara yang berlaku (pasal 18).

9) Hakim tetap berwenang untuk terus mengupayakan perdamaian hingga sebelum pengucapan putusan. Jika para pihak berkeinginan untuk berdamai, maka upaya perdamaian dapat berlangsung paling lama 14 hari kerja, sejak penyampaian keinginan tersebut (pasal 18).

10) Jika para pihak gagal mencapai kesepakatan, pernyataan dan pengakuan para pihak selama proses mediasi tidak dapat dijadikan bukti dalam proses persidangan perkara, catatan mediator wajib dimusnahkan, mediator tidak dapat menjadi saksi dan tidak dapat dikenai pertanggungjawaban pidana maupun perdata (pasal 19). ${ }^{13}$

\section{Pelaksanaan Mediasi di Pengadilan Agama Bangkalan}

Berkenaan dengan pelaksanaan PERMA nomor 1 tahun 2008 di Pengadilan Agama Bangkalan, para pihak yang berperkara, baik

\footnotetext{
13 Resume Prosedur Mediasi menurut PERMA No 1 Tahun 2008.
} 
pada perkara cerai gugat maupun permohonan cerai talak, pada sidang pertama, hakim berupaya melakukan upaya damai dan mewajibkan pada para pihak untuk melakukan proses mediasi, sebab jika mereka tidak menempuh prosedur mediasi, maka berdasarkan peraturan ini, ia merupakan pelanggaran terhadap ketentuan Pasal 130 HIR dan/atau Pasal 154 Rbg yang mengakibatkan putusan batal demi hukum (pasal 2) ayat 3.

Terkadang masih ada para pihak (pemohon/termohon dan penggugat/tergugat) yang menolak dilaksanakannya mediasi, mengingat dengan adanya ruang mediasi akan memperlambat atau memperpanjang pelaksanaan proses perceraian di pengadilan agama, sedangkan mereka menginginkan perceraian secepatnya. ${ }^{14}$ Alasan mereka menolak karena sebelum para pihak mendaftarkan pada pengadilan agama, mereka sudah pernah melakukan perundingan damai yang dilakukan oleh pihak keluarga, atau jika masih belum berhasil, maka difasilitasi oleh kepala desa setempat dan tokoh agama. 15

Pengadilan agama juga memberikan keleluasaan kepada kedua belah pihak untuk menentukan mediator, di samping ruang receptionist. Pengadilan Agama Bangkalan telah mencantumkan nama-nama hakim mediator lengkap dengan foto dan kepangkatannya. Apabila para pihak memilih mediator sendiri, maka di berita acara persidangan akan ditulis oleh hakim majelis. Namun, apabila para pihak menyerahkan penentuan mediator kepada hakim majelis, maka ketua hakim majelis membuat surat penunjukan kepada hakim mediator dengan surat keputusan.16

Mediator yang berasal dari lembaga mediasi, advokat, atau individu harus mempunyai sertifikat mediasi dari Pengadilan Agama Bangkalan. Apabila masih belum memiliki sertifikat, maka ketua Pengadilan Agama Bangkalan membuat SK kepada hakim untuk menjadi hakim mediator di Pengadilan Agama Bangkalan. Menurut hasil penelusuran penulis masih belum ada hakim mediator yang mengikuti pelatihan mediasi secara integral. Hanya ada satu orang,

\footnotetext{
14 Wawancara dengan Hakim Moch. Akhmad, tanggal 10 Desember 2009.

15 Wawancara dengan Hakim Moh. Khasin, tanggal 10 Desember 2009.

16 Hakim mediator yang ditentukan oleh para pihak maupun oleh Ketua Majelis hakim tidak boleh terdiri dari salah satu hakim pemeriksa.
} 
yaitu Alirido, SH., MH., yang memilikinya, namun bentuk pelatihannya tidak utuh.

Secara formal hakim mediator Pengadilan Agama Bangkalan memfasilitasi para mediator selama dua pekan (15 hari) atau lebih, jika para pihak menghendaki perpanjangan mediasi sampai 40 hari. Namun, menurut PERMA mediasi dapat diperpanjang 14 hari kerja sejak berakhir masa 40 hari atas kesepakatan para pihak. Pertemuan mediasi oleh hakim mediator ditentukan minimal dua kali pertemuan dan waktunya diusulkan oleh mediator untuk dibahas dan disepakati. Namun, boleh dilakukan lebih jika para pihak menginginkannya.

Mengingat pertemuan yang dilakukan oleh hakim mediator hanya dua tatap muka, maka menurut teori mediasi tentu pertemuan tersebut belum akan mampu mengungkap permasalahan sampai ke akarnya. Dengan demikian, jika para pihak pasif dan tidak dalam rangka mencari solusi dalam penyelesaian masalahnya, maka pelaksanaan mediasi akan tetap jauh dari kesuksesan.

Pertemuan pertama dilakukan pada minggu pertama dan pertemuan kedua dilakukan pada minggu kedua. Selanjutnya mediator menyarankan kepada pihak-pihak yang berperkara supaya perkara ini diakhiri dengan jalan damai dengan berusaha mengurangi kerugian masing-masing pihak yang berperkara. Ketika proses mediasi dilaksanakan oleh hakim mediator, maka model kerja mediasi hampir mirip dengan bentuk penasihatan dan penggalian data masalah para pihak untuk dicarikan win-win solution tanpa melaui konsep yang matang, sebagaimana tahapan teori mediasi.

Secara teoritik, ada beberapa tahapan mediasi yang harus diperhatikan oleh mediator dalam melakukan memediasi perkara yaitu: Pertama, tahap I, setuju untuk menengahi (agree to mediate). Pada tahap ini persiapan yang harus dilakukan oleh seorang mediator adalah: (1) Meraih dan menemukan kesadaran diri melalui pikiran, perasaan, dan harapan; (2) menentukan waktu yang tepat untuk membahas konflik dari pihak-pihak yang bertikai; (3) menciptakan suasana yang positif bagi kedua belah pihak yang sedang bertikai.

Kedua, tahap II, yakni menghimpun sudut pandang (gather points of view). Pada tahap ini persiapan yang bisa yang harus dilakukan oleh mediator adalah: (1) Melakukan penuturan cerita (story-telling), dan membiarkan pihak-pihak yang sedang bertikai 
untuk menuturkan cerita mereka tanpa diinterupsi; (2) menggunakan ketrampilan berkomunikasi secara efektif.

Ketiga, tahap III, yaitu memusatkan perhatian pada kebutuhan (focus on interest). Pada tahap ini persiapan yang bisa dilakukan oleh mediator adalah menggali lebih dalam mengenai kebutuhan (interest) dari masing-masing pihak yang sedang bertikai dengan mengajak mereka berdialog untuk menggali pokok permasalahan dan kebutuhan mereka. Hal tersebut bisa dilakukan dengan cara: (1) Melihat apa yang ada di bawah batas posisi dan kebutuhan masingmasing pihak yang bertikai setelah itu meditor mengklarifikasi pokok permasalahan tersebut, sehingga mediator dapat memahami situasinya dengan baik; (2) merangkum dengan baik permasalahan maupun kebutuhan dari masing-masing pihak yang sedang bertikai.

Keempat, tahap IV, yaitu menciptakan pilihan terbaik (create win-win options). Pada tahap ini mediator membantu pihak-pihak yang bertikai untuk mencarikan solusi bagi permasalahan mereka dengan cara memberikan beberapa ide/gagasan (brainstorm solutions). Ini bisa ditempuh dengan cara: (1) Sebisa mungkin mendapatkan ideide untuk solusi menang/menang; (2) bersikap kreatif dan jangan menyalahkan ide-ide yang disampaikan oleh masing-masaing pihak yang bertikai selama proses penyampaian ide; (3) melakukan evaluasi terhadap solusi yang ditawarkan oleh masing-masing pihak yang bertikai untuk dipelajari lebih lanjut sehingga akan ditemukan solusi mana yang paling tepat untuk penyelesaian suatu konflik. Jika tidak ada solusi yang didapat maka mediator harus mengulangi lagi proses penyelesaian konflik dan mempelajari kembali langkah-langkah dari awal; (4) memilih solusi yang disetujui oleh para pihak yang sedang berkonflik. Jika tidak ada solusi yang disepakati maka mediator harus meneruskan brainstorming, atau mengulangi langkah-langkah penyelesaian dari awal. Hal ini bisa mungkin terjadi, karena mediator belum sampai ke permasalahan "yang sebenarnya".

Kelima, tahap V, yaitu mengevaluasi pilihan (eEvaluate options). Jika opsi telah ditemukan, maka mediator harus memeriksa kembali opsi tersebut untuk memastikan bahwa konflik tersebut benar-benar telah diselesaikan atau ditemukan penyelesaiannya.

Keenam, tahap VI, yaitu menciptakan kesepakatan (create an agreement). Pada tahap ini mediator harus mampu merumuskan solusi/resolusi dari suatu konflik dalam rumusan yang jelas dengan 
Adiyono

cara: (1) Membuat solusi dalam rumusan yang sejelas mungkin (mengenai siapa, apa, kapan, dan bagaimana); (2) membicarakan kondisi "bagaimana jika". Mediator bisa meminta pihak-pihak yang bertikai untuk mengatakan apa yang akan mereka lakukan jika mereka tidak dapat memenuhi kesepakatan yang mereka buat tersebut; (3) mengakui keberhasilan pihak-pihak yang bertikai dalam mencapai kesepakatan. Mediator harus mengucapkan terima kasih kepada pihak-pihak yang bertikai atas kesediaan mereka bekerja sama melakukan semuanya. ${ }^{17}$

Pada waktu maksimal dua pekan atau dua kali tatap muka dalam mediasi para pihak tidak mengajukan waktu tambahan sebagaimana dimaksud di PERMA dan para pihak tidak sepakat atau sepakat damai, maka mediator memberikan laporan secara tertulis yang direkomendasikan kepada ketua majelis hakim atas hasil mediasi yang telah dilakukan secara jelas dan ringkas. Namun, dalam kekentuan PERMA Pasal 17 (mencapai Kesepakatan), jika mediasi menghasilkan kesepakatan perdamaian, para pihak dengan bantuan mediator wajib merumuskan secara tertulis kesepakatan yang dicapai dan ditandatangani oleh para pihak dan mediator ayat 1 (satu). Jika dalam proses mediasi para pihak diwakili oleh kuasa hukum, para pihak wajib menyatakan secara tertulis persetujuan atas kesepakatan yang dicapai ayat 2 (dua).

\section{Dampak Pelaksanaan Mediasi di Pengadilan Agama}

Dari beberapa perkara perceraian dengan bermacam motif, maka dapat penulis dapat mengemukakan tiga hal, yaitu perbedaan mediasi sebelum dan pasca mediasi, problematika mediasi, dan data perkara sebelum mediasi dan pasca mediasi.

Pertama, perbedaan sebelum adanya mediasi dan pasca mediasi. Pembahasan ini kami difokuskan pada beberapa perbedaan dari pendapat hakim di Pengadilan Agama Bangkalan dengan adanya PERMA nomor 1 tahun 2008 yang dilaksanakan oleh Pengadilan Agama Bangkalan sejak diberlakukannya pada bulan Januari 2009 sampai dengan penelitian ini dilakukan oleh penulis.

17 M. Muhsin Jamil, Mengelola Konflik Membangun Damai (Semarang: Walisongo Mediation Centre, 2007), hlm. 111-113. 
Menurut pendapat hakim yang telah melaksanakan mediasi selama 10 bulan lebih di Pengadilan Agama Bangkalan, mediasi dapat menekan perceraian, meskipun tingkat keberhasilannya masih kecil, sebab masih banyak hal yang perlu diperbaiki dalam bermediasi. Adanya mediasi di Pengadian Agama Bangkalan membuat tugas hakim bertambah, sebab masih belum adanya mediator bersertifikat. 18 Ini berakibat pada tugas dan tanggungjawab hakim dalam menyelesaikan tidak fokus. Namun demikian, mediasi yang difasilitasi oleh mediator yang mempunyai pengetahuan luas tentang mediasi akan berdampak positif bagi beberapa perkara perceraian, terutama dalam memberikan win-win solution..$^{19}$

Kedua, problematika implementasi mediasi. Problematika mediasi dan lemahnya pelaksanaan mediasi di pengadilan Agama Bangkalan adalah karena: (1) Mediator 100\% dari hakim dan umumnya mereka belum mempunyai pedidikan tentang mediasi; (2) waktu mediasi rata-rata 30 menit sampai 1 jam, bahkan kadangkadang 15 menit; (3) mediasi berbentuk nasihat; (4) kendala yang dihadapi adalah pengetahuan dan keterampilan mediator, bertambahnya beban kerja di samping sebagai mediator, juga sebagai ketua majelis dan anggota majelis, jika mediasi gagal, pernyataan dan pengakuan para pihak dalam proses mediasi tidak bisa dijadikan bukti sebab mediator tidak jadi saksi dalam sidang; (5) belum adanya tambahan insentif bagi hakim mediator; (6) belum adanya reward kepada hakim mediator yang berhasil dalam mendamaikan bagi para pihak yang berperkara dari lembaga pengadilan agama; (7) di Madura kecenderungan masyarakatnya yang datang ke pengadilan agama benar-benar sudah beriktikad kuat ingin bercerai, mengingat sebelum menyerahkan perkaranya ke pengadilan agama sudah sering didamaikan baik oleh keluarganya maupun tokoh masyarakat dan tojoh agama yang disegani.20

Penutup

Dari paparan di atas dapat disimpulkan sebagai berikut:

Pertama, prosedur mediasi sebagaimana ketentuan Perma No. 01 tahun 2008 di Pengadilan Agama Bangkalan sudah diaplikasikan

18 Wawancara dengan Nurlina, tanggal 13 November 2009

19 Ibid.

20 Wawancara dengan Hakim Mediator PA. Bangkalan, tanggal 14 November 2009 
meskipun kemampuan mediator masih belum maksimal sebagaimana dalam kajian teoritik mediasi.

Kedua, dampak pelaksanaan mediasi yang dilakukan oleh hakim mediator Pengadilan Agama Bangkalan mampu meningkatkan keberhasilan 3.0\% dibandingkan dengan tahun 2008 sebelum adanya mediasi. Namun, jika dibandingkan dengan jumlah perkara perceraian di Pengadilan Agama Bangkalan masih belum dikatakan berhasil sebab angkanya hanya meningkat $3.0 \%$.

Ketiga, mediasi dalam hukum Islam memang dijadikan sebagai alternatif kebuntuan masalah dalam rangka mencari keadilan, meskipun lafadznya tidak sama, namun secara maksud dan tujuannya sama-sama ingin mencari rasa keadilan.

\section{Daftar Pustaka:}

Abbas, Syahrizal. Mediasi dalam Perspektif Hukum Syari'ah, Hukum Adat dan Hukum Nasional. Jakarta: Fajar Interpratama offset, 2009.

Fajari, Zainuddin. "Mediasi", Makalah disampaikan pada acara Orientasi Peningkatan Kemampuan Kepemimpinan Hakim Pengadilan Agama di Surabaya 15 April 2009.

Goopaster, Gary. Negosiasi dan Mediasi: Sebuah Pedoman Negosiasi dan Penyelesaian Sengketa melalui Negosiasi. Jakarta: Elips Project, 1993.

Jamil, M. Muhsin. Mengelola Konflik Membangun Damai. Semarang: Walisongo Mediation Centre, 2007.

Permana, Sugiri. “Mediasi dan Hakam dalam Tinjauan Hukum Acara Peradilan Agama", Mari (2009).

Spencer, David, dan Brogan, Michael. Mediation Law and Practice. Cambridge: Cambridge Univercuty Press, 2006.

Tim Penyusun Pusat Pembinaan dan Pengembangan Bahasa, Kamus Besar Bahasa Indonesia. Jakarta: Departemen Pendidikan dan Kebudayaan, 2007. 